\title{
Differential effects of retinoic acid on uncoupling protein-1 and leptin gene expression
}

\author{
M V Kumar and $\mathbf{P}$ J Scarpace \\ Geriatric Research, Education and Clinical Center, Department of Veterans Affairs Medical Center, Gainesville, Florida 32608-1197, USA and Department of \\ Pharmacology and Therapeutics, University of Florida College of Medicine, Gainesville, Florida 32610, USA \\ (Requests for offprints should be addressed to P J Scarpace, Geriatric Research, Education and Clinical Center (182), Department of Veterans Affairs Medical \\ Center, Gainesville, Florida 32608-1197, USA)
}

\begin{abstract}
All-trans-retinoic acid (RA), one of the active metabolites of vitamin $\mathrm{A}$, can increase the expression of uncoupling protein-1 (UCP1) gene. To determine whether RA stimulates brown adipose tissue (BAT) thermogenesis and modulates leptin gene expression in vivo, 6-month-old, vitamin-A sufficient, F344 $\times$ BN rats were administered a single dose of RA $\left(7.5 \mathrm{mg} / \mathrm{kg}\right.$, i.p.) or the $\beta_{3}$-adrenergic receptor $\left(\beta_{3} \mathrm{AR}\right)$ specific agonist, CGP 12177 (0.75 mg/ $\mathrm{kg})$. Levels of UCP1 mRNA in BAT and leptin mRNA in perirenal white adipose tissue (WAT) were examined $5 \mathrm{~h}$ after treatment. mRNA levels of lipoprotein lipase (LPL) were also examined in BAT and perirenal WAT. Administration of CGP 12177 caused the expected increase in UCP1 mRNA levels. RA treatment also significantly increased UCP1 mRNA levels but to a lesser extent
\end{abstract}

than CGP 12177. In contrast, there was no acute effect of RA on whole body oxygen consumption, one measure of BAT thermogenesis. Both CGP 12177 and RA treatment decreased levels of leptin mRNA to a similar extent. RA treatment had no effect on mRNA levels of LPL in BAT or perirenal WAT. There were no changes in total DNA content, total protein content, or in the levels of $\beta$-actin mRNA in either BAT or perirenal WAT upon administration of RA or CGP 12177. Thus, the acute effects of RA paralleled the effects of the $\beta_{3} A R$ specific agonist, CGP 12177, on UCP1 and leptin gene expression. This involvement of RA in positive regulation of UCP1 mRNA and negative regulation of leptin mRNA suggests a contrasting role for RA in energy homeostasis. Journal of Endocrinology (1998) 157, 237-243

\section{Introduction}

Thermogenesis in brown adipose tissue (BAT) serves not only as a regulator of body temperature but also as a means for the dissipation of large quantities of energy as heat. Due to its function in energy expenditure and energy balance, BAT has been implicated in playing an important role in the control of obesity (Hamman et al. 1996). The key element in BAT thermogenesis is the unique expression of a mitochondrial protein called uncoupling protein-1 (UCP1). UCP1 is a proton carrier that, upon activation, causes the uncoupling of respiration from oxidative phosphorylation, thus causing dissipation of energy as heat. The UCP1 gene is under strict transcriptional control in relation to BAT development and heat demand.

Another gene that has recently been identified as playing an important role in energy homeostasis is the ob gene (Murakami \& Shima 1995, Pelleymounter et al. 1995). The product of the ob gene, leptin, appears to be expressed and secreted exclusively in white adipose tissue (WAT). Leptin is believed to be the signal for the level of adiposity, and this hormone both suppresses food intake and increases energy expenditure (Meier 1995, Scarpace et al. 1997).
The sympathetic nervous system plays an integral role in the regulation of UCP1 and leptin gene expression (Himms-Hagen 1990, Campfield et al. 1995). UCP1 gene induction in BAT is largely mediated by the sympathetic activation of $\beta_{3}$-adrenergic receptors $\left(\beta_{3} A R\right)$. Following administration of a $\beta_{3} \mathrm{AR}$ specific agonist, there is a tremendous increase in levels of UCP1 mRNA in BAT (Scarpace et al. 1996). Sympathetic stimulation via $\beta_{3}$ ARs has also been implicated in the negative regulation of leptin gene expression in WAT (Mantzoros et al. 1996). We recently demonstrated a $\beta_{3} \mathrm{AR}$-mediated suppression of leptin gene expression in WAT in rats (Li et al. 1997). In addition to sympathetic stimulation, UCP1 and leptin gene expression are also regulated by other hormones such as glucocorticoids (Moriscot et al. 1993, De Vos et al. 1995).

All-trans-retinoic acid (RA), one of the active metabolites of vitamin A, has recently been described as yet another novel player in the regulation of UCP1 gene expression (Alvarez et al. 1995, Puigserver et al. 1996). The action of RA as a transcriptional activator of the UCP1 gene has been described in brown adipocytes (Alvarez et al. 1995, Rabelo et al. 1996). Another study 
described the induction of UCP1 gene expression upon chronic administration of RA in mice (Puigserver et al. 1996). In contrast, little is known as to whether RA acutely increases thermogenesis in BAT apart from the induction of UCP1 gene expression. In addition, the effects of RA on leptin gene expression are unknown. We hypothesized that RA, when given as an acute dose to vitamin A-sufficient animals, would stimulate BAT thermogenesis and suppress leptin gene expression in a manner similar to $\beta_{3} \mathrm{AR}$ specific agonists. To this end, we administered a single dose of RA and the $\beta_{3} \mathrm{AR}$ specific agonist, CGP 12177, to $\mathrm{F} 344 \times \mathrm{BN}$ rats and examined whole body oxygen consumption, UCP1 mRNA levels in BAT, and leptin mRNA levels in perirenal WAT. We also assessed mRNA levels of lipoprotein lipase (LPL) in BAT and perirenal WAT.

\section{Materials and Methods}

\section{Animals}

Male F344 $\times$ BN rats, 6 months of age, were obtained from Harlan Sprague-Dawley (Indianapolis, IN, USA). Upon arrival, rats were examined and remained in quarantine for one week. Animals were cared for in accordance with the principles of the Guide and Use of Experimental Animals. Rats were housed individually in micro-isolated cages with a $12 \mathrm{~h}$ light: $12 \mathrm{~h}$ darkness cycle (lights on from 0700 to $1900 \mathrm{~h}$ ) and maintained on Rat Chow (Purina) ad libitum. Ambient temperature was $26^{\circ} \mathrm{C}$.

\section{Chemicals}

CGP 12177 was a gift from Ciba-Geigy (Summit, NJ, USA) and was prepared in pyrogen-free saline. Methylprednisolone sodium succinate was obtained from The Upjohn Co. (Kalamazoo, MI, USA). All other chemicals, including all-trans-retinoic acid, were obtained from Sigma Chemical (St Louis, MO, USA). All-trans-retinoic acid was prepared in 50\% dimethylsulfoxide, 50\% ethanol.

\section{Oxygen consumption}

Oxygen consumption was assessed in up to four rats simultaneously with an Oxyscan analyzer (OXS-4; Omnitech Electronics, Columbus, OH, USA) as described previously (Scarpace \& Matheny 1996). Flow rates were $21 /$ min with a 30 -s sampling time at 5 -min intervals. The temperature was maintained at $26^{\circ} \mathrm{C}$. Results were expressed on a mass-dependent basis $\left(\mathrm{ml} / \mathrm{min} / \mathrm{kg}^{0 \cdot 67}\right)$. All experiments were performed on conscious unanesthetized rats during the light phase of the light-darkness cycle.

\section{Tissue harvesting}

Rats were killed by cervical dislocation under $90 \mathrm{mg} / \mathrm{kg}$ pentobarbital anesthetic. The circulatory system was perfused with $40 \mathrm{ml}$ cold saline, and BAT and perirenal WAT were excised, weighed, and rapidly stored in liquid nitrogen. The tissues were stored at $-70{ }^{\circ} \mathrm{C}$ until analysis.

$m R N A$ levels of UCP1, leptin, and LPL

Total cellular RNA was extracted using a modification of the method of Chomczynski and Sacchi (1987). The integrity of the isolated RNA was verified using 1\% agarose gels stained with ethidium bromide. The RNA was quantified by spectrophotometric absorption at $260 \mathrm{~nm}$ using multiple dilutions of each sample.

The probe to detect leptin mRNA was a 33-mer antisense oligonucleotide (5'-GGTCTGAGGCAGGGA GCAGCTCTTGGAGAAGGC) (Trayhurn et al. 1995a), end-labeled using terminal deoxynucleotidyl transferase (Promega, Madison, WI, USA). The oligonucleotide was based on a region of the mRNA downstream from the site of the primary mutation in ob/ob mice and synthesized at the University of Florida core facility and verified by Northern analysis as previously described (Li et al. 1997). The full length cDNA clone for UCP1 was kindly provided by Dr L Kozak, Jackson Laboratory, Bar Harbor, Maine, USA (Kozak et al. 1988) and verified by Northern analysis, as previously described (Scarpace et al. 1994). The UCP1 cDNA probe and the full length human $\beta$-actin cDNA probe (Clontech, Palo Alto, CA, USA) and the mouse LPL cDNA clone (ATCC, Rockville, MD, USA) were random prime labeled using Prime-a-Gene (Promega).

For dot-blot analysis, multiple concentrations of RNA were immobilized on nylon membranes using a dot-blot apparatus (BioRad, Richmond, CA, USA). The membranes were baked at $80{ }^{\circ} \mathrm{C}$ for $2 \mathrm{~h}$. The baked membranes were prehybridized using $25 \mathrm{mM}$ potassium phosphate, $750 \mathrm{mM} \mathrm{NaCl}, 75 \mathrm{mM}$ Na citrate, $5 \times$ Denhardt's solution, $50 \mu \mathrm{g} / \mathrm{ml}$ denatured salmon sperm DNA, and $50 \%$ formamide. After incubation for $14-16 \mathrm{~h}$ at $42{ }^{\circ} \mathrm{C}$, the membranes were hybridized with ${ }^{32} \mathrm{P}-$ labeled probes in the prehybridization buffer plus $10 \%$ dextran sulfate. After hybridization for $14-16 \mathrm{~h}$ at $42{ }^{\circ} \mathrm{C}$, the membranes were washed and exposed to a phosphor imaging screen for $48 \mathrm{~h}$. The latent image was scanned using a Phosphor Imager (Molecular Dynamic, Sunnyvale, CA, USA) and analyzed by Image Quant Software (Molecular Dynamics). Intensities per $\mu \mathrm{g}$ total cellular RNA were calculated by comparison to internal laboratory standards of WAT or BAT total RNA present on each nylon membrane.

\section{Protein}

Total protein was estimated by the method of Bradford (1976).

\section{$D N A$}

Total DNA was determined by fluorimetric assay in delipidated tissue, using bisBENZIMIDE (Labarca \& 


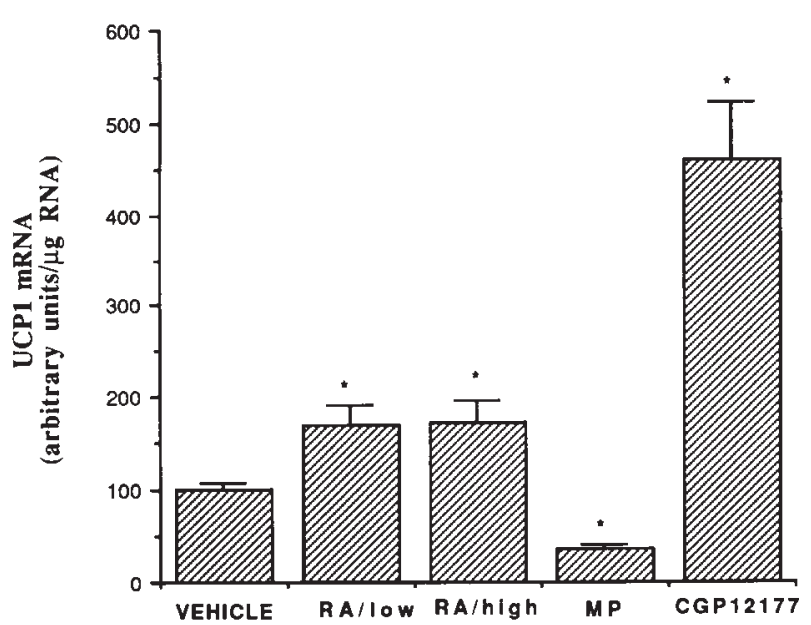

Figure 1 UCP1 mRNA levels in BAT following administration of vehicle, RA (low dose, $7.5 \mathrm{mg} / \mathrm{kg}$; high dose, $22.5 \mathrm{mg} / \mathrm{kg}$ ), methylprednisolone (MP, $65 \mathrm{mg} / \mathrm{kg}$, 2 doses, $24 \mathrm{~h}$ apart), or CGP $12177(0 \cdot 75 \mathrm{mg} / \mathrm{kg})$. Animals were killed $5 \mathrm{~h}$ post-injection. (For $\mathrm{MP}$, animals were killed $5 \mathrm{~h}$ after the last dose.) Data represent means \pm S.E. of $6-8$ rats in each treatment group. UCP1 mRNA levels are expressed in arbitrary units/ $\mu \mathrm{g}$ RNA, with the level of UCP1 mRNA in vehicle controls set to $100 .{ }^{*} P<0 \cdot 05$ compared with vehicle controls (Student's t-test).

Paigen 1980). BAT $(30 \mathrm{mg})$ or perirenal WAT $(90 \mathrm{mg})$ were sonicated on ice for $15 \mathrm{~s}$ in $500 \mu \mathrm{l}$ PSE buffer (50 mM sodium phosphate, $\mathrm{pH} 7 \cdot 4,2 \mathrm{M} \mathrm{NaCl}, 1 \mathrm{mM}$ EDTA). The tissue was delipidified by addition of $7 \mathrm{ml}$ acetone $\left(-20{ }^{\circ} \mathrm{C}\right)$, followed by mixing for $20 \mathrm{~min}$ and centrifugation at $1800 \boldsymbol{g}$ for $10 \mathrm{~min}$. The pellet was harvested and resuspended in PSE buffer. Fluorescence of appropriate aliquots of each sample was read in PSE buffer $+1 \mu \mathrm{g} / \mathrm{ml}$ bisBENZIMIDE, at emission wavelength of $460 \mathrm{~nm}$, in a Hoefer (San Francisco, CA, USA) Fluormeter, Model TKO 100.
Data analysis

One-way analysis of variance was applied. When the main effect was significant, Dunner's analysis was applied. If standard deviation was nonhomogenous, then data were first subjected to $\log$ transformation and then statistical analysis (this occurred only for protein data in BAT (Table 1)).

\section{Results}

\section{UCP1 $m R N A$}

The acute effects of a single dose of RA $(7 \cdot 5 \mathrm{mg} / \mathrm{kg}$, i.p.) on UCP1 mRNA levels in BAT were examined in vitamin A-sufficient $\mathrm{F} 344 \times \mathrm{BN}$ rats. $\mathrm{RA}$ induced a $70 \%$ increase in UCP1 mRNA levels that was highly significant compared with controls (Fig. 1). The effects of RA on UCP1 mRNA levels were compared with the effects of the $\beta_{3}$ AR specific agonist, CGP 12177 (0.75 mg/kg, i.p.), and the glucocorticoid, methylprednisolone $(65 \mathrm{mg} / \mathrm{kg}, 2$ doses, $24 \mathrm{~h}$ apart, s.c.). Levels of UCP1 mRNA in all treatment groups were examined $5 \mathrm{~h}$ after the last injection. UCP1 gene expression induced by CGP 12177 increased by $360 \%$ compared with controls, whereas methylprednisolone resulted in a $65 \%$ reduction in UCP1 mRNA levels (Fig. 1). In contrast to the changes in UCP1 mRNA levels, administration of RA, CGP 12177, or methylprednisolone did not significantly change levels of $\beta$-actin mRNA compared with controls (Table 1). The total DNA and protein content in BAT were also unchanged in the four treatment groups (Table 1). In a second experiment, the acute effects of a higher dose of RA $(22.5 \mathrm{mg} / \mathrm{kg}$, i.p.) on UCP1 mRNA levels were examined. There was a $72 \%$ increase in UCP1 mRNA levels following administration of a higher dose of RA $(22.5 \mathrm{mg} / \mathrm{kg})$, which was similar to that seen with the lower dose of RA $(7 \cdot 5 \mathrm{mg} / \mathrm{kg})$ (Fig. 1).

Table 1 Levels of total DNA, total protein and $\beta$-actin mRNA in BAT following administration of vehicle, RA, methylprednisolone (MP), or CGP 12177. Animals received either vehicle, RA $(7.5 \mathrm{mg} / \mathrm{kg}), \mathrm{MP}(65 \mathrm{mg} / \mathrm{kg}, 2$ doses, $24 \mathrm{~h}$ apart), or CGP 12177 $(0 \cdot 75 \mathrm{mg} / \mathrm{kg})$. Tissues were collected $5 \mathrm{~h}$ after treatment with vehicle, RA, CGP 12177 or MP. Data represent means \pm S.E. of $6-8$ rats in each treatment group. $\beta$-actin mRNA levels are expressed in arbitrary units/ $\mu \mathrm{g}$ RNA, with the level in vehicle controls set to 100 with proportional S.E.

\begin{tabular}{|c|c|c|c|}
\hline & $\begin{array}{l}\text { DNA } \\
(\mu \mathrm{g} / \mathrm{BAT})\end{array}$ & $\begin{array}{l}\text { Protein } \\
(\mathrm{mg} / \mathrm{BAT})\end{array}$ & $\begin{array}{l}\boldsymbol{\beta} \text {-actin mRNA } \\
\text { (arbitrary units/ } \mu \mathrm{g} \text { RNA) }\end{array}$ \\
\hline \multicolumn{4}{|l|}{ Treatment } \\
\hline Vehicle & $368 \pm 29$ & $24 \pm 4$ & $100 \cdot 0 \pm 12 \cdot 9$ \\
\hline RA & $332 \pm 30$ & $16 \pm 1$ & $93 \cdot 4 \pm 12 \cdot 2$ \\
\hline MP & $326 \pm 60$ & $16 \pm 0 \cdot 6$ & $81 \cdot 2 \pm 5 \cdot 2$ \\
\hline CGP 12177 & $304 \pm 14$ & $16 \pm 0 \cdot 4$ & $94 \cdot 0 \pm 8 \cdot 9$ \\
\hline
\end{tabular}

There were no statistical differences in the levels of total DNA, total protein, and $\beta$-actin mRNA in BAT among the four treatment groups. 


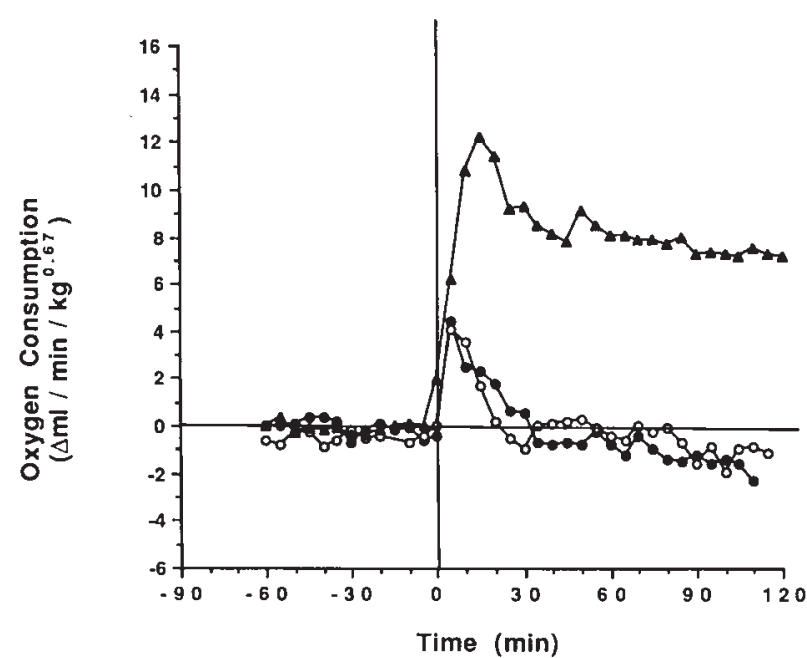

Figure 2 Increase $\left(\triangle \mathrm{ml} / \mathrm{min} / \mathrm{kg}^{0.67}\right)$ over baseline in oxygen consumption after administration of RA $(22.5 \mathrm{mg} / \mathrm{kg})(\mathbf{O})$, CGP $12177(0 \cdot 75 \mathrm{mg} / \mathrm{kg})(\boldsymbol{\Delta})$, or vehicle $(\bigcirc)$. Mean body weights were $397 \pm 6 \mathrm{~g}, 382 \pm 10 \mathrm{~g}$, and $426 \pm 16 \mathrm{~g}$ for RA-, CGP 12177- and vehicle-treated groups respectively. Mean baseline values were $13 \cdot 7 \pm 1 \cdot 1,11 \cdot 2 \pm 0 \cdot 2$, and $13.4 \pm 0 \cdot 4 \mathrm{ml} / \mathrm{min} / \mathrm{kg}^{0 \cdot 67}$ for RA-, CGP 12177- and vehicle-treated rats respectively. Data represent means of 8 rats for RA-treated group and 4 rats for CGP 12177- and vehicle-treated groups. Standard error of mean bars ranged from 0.4 to 0.8 for RA-treated group, from 0.4 to 0.9 for CGP 12177 treated group, and from $0 \cdot 2$ to $0 \cdot 8$ for vehicle-treated group.

\section{Oxygen consumption}

To assess whether RA induced an acute activation of BAT thermogenesis, the immediate time-course response of whole body oxygen consumption was examined following i.p. administration of RA $(22.5 \mathrm{mg} / \mathrm{kg})$, CGP 12177 $(0.75 \mathrm{mg} / \mathrm{kg})$, or vehicle. The process of injecting the rats with RA or vehicle caused a transient increase in oxygen consumption. However, there was no significant sustained change in oxygen consumption with RA compared with controls over 2 h (Fig. 2). In contrast, CGP 12177 resulted in a rapid increase in oxygen consumption that was sustained for longer than $1 \mathrm{~h}$. In some rats, oxygen consumption was examined for $5 \mathrm{~h}$ after administration of RA, but again no increases in oxygen consumption were observed (data not shown).

\section{Leptin $m R N A$}

To determine whether leptin expression is regulated by $\mathrm{RA}$, in a manner similar to that by $\beta_{3} \mathrm{AR}$ agonists, levels of leptin mRNA were examined in perirenal WAT after a single dose of RA $(7.5 \mathrm{mg} / \mathrm{kg}$, i.p.). Once again, the effects of RA on leptin mRNA were compared with the effects of CGP $12177(0.75 \mathrm{mg} / \mathrm{kg}$, i.p.), methylprednisolone (65 mg/kg, 2 doses, 24 h apart, s.c.), and vehicle. Levels of leptin mRNA were examined $5 \mathrm{~h}$ after the last injection in all treatment groups. Administration of RA

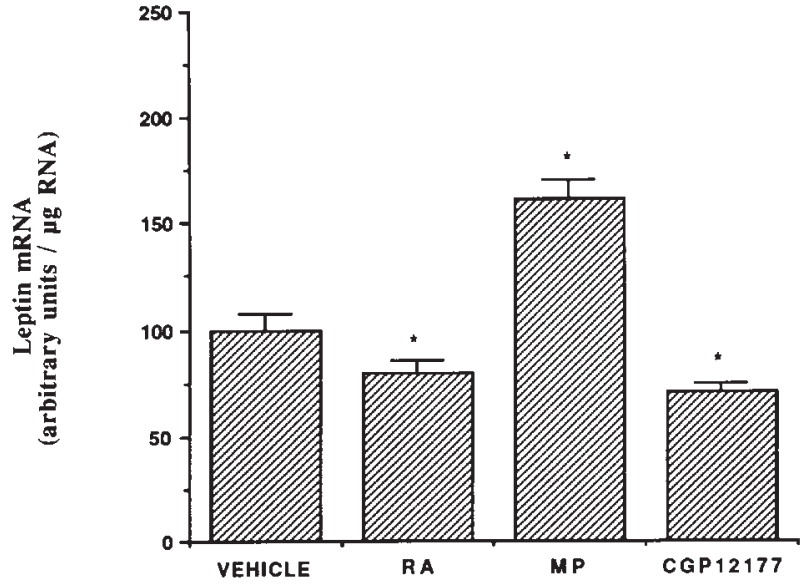

Figure 3 Leptin mRNA levels in perirenal WAT following administration of vehicle, RA $(7.5 \mathrm{mg} / \mathrm{kg})$, methylprednisolone (MP, $65 \mathrm{mg} / \mathrm{kg}, 2$ doses, $24 \mathrm{~h}$ apart), or CGP 12177 (0.75 mg/kg).

Animals were killed $5 \mathrm{~h}$ post-injection. (For MP, animals were killed $5 \mathrm{~h}$ after the last dose.) Data represent means \pm S.E. of $6-8$ rats in each treatment group. Leptin mRNA levels are expressed in arbitrary units/ $\mu \mathrm{g}$ RNA, with the levels of leptin mRNA in vehicle controls set to $100 .{ }^{*} P<0 \cdot 05$ compared with vehicle control rats (Student's t-test).

and CGP 12177 induced comparable decreases in levels of leptin mRNA $(21 \pm 4 \%$ and $29 \pm 2 \%$ respectively) (Fig. 3). In contrast, methylprednisolone induced a $61 \%$ increase in levels of leptin mRNA compared with controls. There were no changes in levels of $\beta$-actin mRNA, total protein, or total DNA in perirenal WAT with the different treatments (Table 2).

\section{LPL $m R N A$}

We further investigated whether RA administration mimicked the effects of CGP 12177 on gene expression of LPL, another protein involved in energy balance. Levels of LPL mRNA were assessed in BAT and perirenal WAT after administration of a single dose of RA $(7.5 \mathrm{mg} / \mathrm{kg}$, i.p.) and CGP 12177 (0.75 mg/kg, i.p.). LPL mRNA levels in BAT were increased by $96 \%$ upon administration of CGP 12177; RA, however, had no effect on LPL mRNA levels in BAT (Table 3). In perirenal WAT, LPL mRNA levels were unchanged upon administration of either RA or CGP 12177 (Table 3). In contrast, upon methylprednisolone administration, there was induction of LPL mRNA levels in both BAT and perirenal WAT (Table 3).

\section{Discussion}

The present report demonstrates that the acute effects of RA parallel the effects of the $\beta_{3} \mathrm{AR}$ specific agonist, CGP 12177, on UCP1 gene expression in BAT and leptin gene expression in perirenal WAT. In contrast, whereas CGP 
Table 2 Levels of total DNA, total protein and $\beta$-actin mRNA in perirenal WAT (PWAT) following administration of vehicle, RA, methylprednisolone (MP), or CGP 12177. Animals received either vehicle, RA $(7.5 \mathrm{mg} / \mathrm{kg}), \mathrm{MP}(65 \mathrm{mg} / \mathrm{kg}$, 2 doses, $24 \mathrm{~h}$ apart), or CGP $12177(0.75 \mathrm{mg} / \mathrm{kg})$. Tissues were collected $5 \mathrm{~h}$ after treatment with vehicle, RA, CGP 12177 or MP. Data represent means \pm S.E. of $6-8$ rats in each treatment group. $\beta$-actin mRNA levels are expressed in arbitrary units/ $\mu \mathrm{g}$ RNA, with the level in vehicle controls set to 100 with proportional S.E.

\begin{tabular}{|c|c|c|c|}
\hline & $\begin{array}{l}\text { DNA } \\
(\mu \mathrm{g} / \mathrm{PWAT})\end{array}$ & $\begin{array}{l}\text { Protein } \\
(\mathrm{mg} / \mathrm{PWAT})\end{array}$ & $\begin{array}{l}\boldsymbol{\beta} \text {-actin mRNA } \\
\text { (arbitrary units/ } \mu \mathrm{g} \text { RNA) }\end{array}$ \\
\hline \multicolumn{4}{|l|}{ Treatment } \\
\hline Vehicle & $132 \pm 14$ & $6 \cdot 0 \pm 0 \cdot 3$ & $100 \cdot 0 \pm 5 \cdot 8$ \\
\hline RA & $179 \pm 23$ & $7 \cdot 0 \pm 0 \cdot 9$ & $92 \cdot 5 \pm 5 \cdot 6$ \\
\hline MP & $192 \pm 32$ & $7 \cdot 8 \pm 1 \cdot 0$ & $87 \cdot 6 \pm 10 \cdot 5$ \\
\hline CGP 12177 & $163 \pm 15$ & $6 \cdot 7 \pm 0 \cdot 8$ & $87 \cdot 9 \pm 10 \cdot 0$ \\
\hline
\end{tabular}

Table 3 Levels of LPL mRNA in BAT and perirenal WAT following administration of vehicle, RA, methylprednisolone (MP), or CGP 12177. Animals received either vehicle, RA $(7 \cdot 5 \mathrm{mg} / \mathrm{kg}), \mathrm{MP}$ (65 mg/kg, 2 doses, $24 \mathrm{~h}$ apart), or CGP 12177 (0.75 mg/kg). Tissues were collected $5 \mathrm{~h}$ after treatment with vehicle, RA, CGP 12177 or MP. Data represent means \pm S.E.M. of $6-8$ rats in each treatment group. LPL mRNA levels are expressed in arbitrary

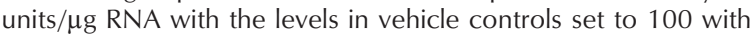
proportional S.E.

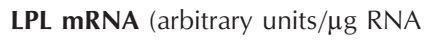

\begin{tabular}{lc}
\hline BAT & Perirenal WAT \\
\cline { 1 - 1 } & \\
$100 \cdot 0 \pm 8 \cdot 5$ & $100 \cdot 0 \pm 4 \cdot 5$ \\
$106 \cdot 8 \pm 9 \cdot 2$ & $86 \cdot 1 \pm 6 \cdot 2$ \\
$149 \cdot 6 \pm 7 \cdot 2^{*}$ & $88 \cdot 6 \pm 5 \cdot 3$ \\
$196 \cdot 2 \pm 23 \cdot 7^{*}$ & $124 \cdot 7 \pm 2 \cdot 9^{*}$
\end{tabular}

${ }^{*} P<0 \cdot 05$ compared with vehicle-treated animals (Student's $t$-test).

12177 greatly enhanced whole body oxygen consumption, there were no acute effects of RA on whole body oxygen consumption, one measure of BAT thermogenesis.

Upon administration of a single dose of RA to vitamin-A sufficient rats, there was induction of UCP1 gene expression, in $5 \mathrm{~h}$, similar to that seen with the $\beta_{3} \mathrm{AR}$ specific agonist, CGP 12177 (Scarpace et al. 1996); however, UCP1 gene induction following administration of CGP 12177 was far greater than that seen with RA $(360 \%$ vs $70 \%$ respectively). In contrast, neither RA nor CGP 12177 altered the levels of $\beta$-actin mRNA levels. Thus, the effects of RA were specific on UCP1 gene expression and paralleled the effects of CGP 12177 on UCP1 gene expression qualitatively, although not quantitatively. In addition, administration of methylprednisolone resulted in the expected decrease in the levels of UCP1 mRNA, providing further evidence that the RA-induced increase in UCP1 gene expression was specific. This effect of methylprednisolone on UCP1 mRNA was similar to that reported earlier (Moriscot et al. 1993).
Our observation indicating an RA-induced increase in UCP1 gene expression is consistent with other reports (Alvarez et al. 1995, Puigserver et al. 1996, Rabelo et al. 1996). These reports demonstrated an increase in UCP1 mRNA following RA treatment in brown adipocytes, differentiated in culture (Alvarez et al. 1995, Rabelo et al. 1996), and in mice upon chronic treatment with RA for 4 days (Puigserver et al. 1996). Although catecholamines are the primary signal for BAT thermogenesis, RA may play an important role as a secondary signal or possibly even a permissive role, in a manner similar to thyroid hormone. Tri-iodothyronine is required for the optimal norepinephrine stimulation of UCP1 gene expression; however, tri-iodothyronine does not increase UCP1 gene expression in the absence of norepinephrine (Bianco et al. 1988, Silva 1988).

The observation that RA increased UCP1 gene expression without stimulating whole body oxygen consumption suggests that RA may play a more important role in the recruitment of BAT thermogenesis, rather than the acute activation of BAT thermogenesis. The recruitment process includes factors that collectively increase the total thermogenic capacity of the tissue, including increased expression of the UCP1 gene, cell proliferation, and mitochondriogenesis (Nedergaard et al. 1995). Although RA increased UCP1 gene expression, there were no changes in either total protein or total DNA content in BAT over the short period of this experiment. However, the former observation raises the possibility that RA may be able to upregulate the capacity for thermogenesis in circumstances where BAT thermogenesis is impaired, such as in senescence (Scarpace et al. 1992). Furthermore, RA may be able to upregulate the capacity for energy expenditure even in cases of normal thermogenesis, by influencing the recruitment process.

Leptin, the product of the recently cloned ob gene, is considered to play an important role in energy balance through its effects on food intake and energy expenditure (Meier 1995); the regulation of leptin gene expression has thus been the subject of intensive investigation. Studies 
have demonstrated upregulation of leptin gene expression by physiological stimuli such as feeding (Trayhurn et al. 1995b) and by hormones such as insulin and glucocorticoids (Saladin et al. 1995, De Vos et al. 1995), whereas suppression of leptin gene expression occurs upon cold exposure (Moinat et al. 1995) or upon in vivo administration of $\beta$-adrenergic agonists (Trayhurn et al. 1995a). Further, recent data suggest that the sympathetic suppression of leptin gene expression is mediated via $\beta_{3} A R s$ in WAT (Mantzoros et al. 1996). The present study demonstrates a decrease in leptin mRNA levels by the $\beta_{3}$ AR specific agonist CGP 12177 in perirenal WAT, similar to other reports (Trayhurn et al. 1995a, Mantzoros et al. 1996, Li et al. 1997). The effects of RA on leptin gene expression paralleled the effects of CGP 12177 and moreover, in this case, the degree of suppression of leptin mRNA levels in perirenal WAT with RA administration was similar to that with the $\beta_{3} \mathrm{AR}$ agonist, CGP 12177 (21\% versus 29\% respectively). $\beta_{3} A R$ s are assuming an important role in the regulation of energy balance. These receptors mediate increased thermogenesis in BAT, increased lipolysis in WAT, and suppression of food intake (Himms-Hagen 1989, Mantzoros et al. 1996, Lowell \& Flier 1997). Paradoxically, $\beta_{3} \mathrm{ARs}$ also mediate the suppression of leptin synthesis (Mantzoros et al. 1996). The former all contribute to an increase in energy expenditure, whereas the latter should promote the opposite, including feeding. The effects of RA and the $\beta_{3}$ AR agonist, CGP 12177 on UCP1 and leptin gene expression, as shown in the present study, demonstrate another paradox. These contrasting effects by RA leave in doubt the overall role of RA on energy balance; that is whether RA, in balance, is contributing to energy expenditure or energy conservation. Whereas the effect of RA on UCP1 gene expression is suggested to be a direct effect through activation of RA-response element on the UCP1 gene (Alvarez et al. 1995, Rabelo et al. 1996), the exact mechanism by which RA suppresses leptin gene expression remains to be investigated. Furthermore, the effect of methylprednisolone in perirenal WAT was opposite to that of RA or CGP 12177. Following administration of methylprednisolone, there was a $61 \%$ increase in leptin mRNA levels. The latter observation corroborates other reports of effects of glucocorticoids on leptin gene expression in mice (Moriscot et al. 1993).

The enzyme LPL is involved in the assimilation of triglycerides into BAT and WAT (Auwerx et al. 1992) and is involved in the regulation of energy balance. Upon CGP 12177 treatment, there was an upregulation of LPL mRNA in BAT but not in perirenal WAT. This is consistent with other reports showing upregulation of LPL mRNA levels by $\beta$-adrenergic stimulation in BAT (Auwerx et al. 1992, Trayhurn et al. 1995a). RA, however, had no effect on LPL mRNA levels in either BAT or perirenal WAT. Methylprednisolone increased LPL mRNA levels in BAT and perirenal WAT.
In summary, the present study demonstrates that RA, when given as an acute dose to vitamin A-sufficient animals, increases UCP1 gene expression in BAT and suppresses leptin gene expression in perirenal WAT. Furthermore, these effects of RA closely mimic the effects of the $\beta_{3} \mathrm{AR}$ specific agonist CGP 12177 on UCP1 and leptin gene expression. The involvement of RA in positive regulation of UCP1 mRNA and negative regulation of leptin mRNA suggests a contrasting role for RA in energy homeostasis.

\section{Acknowledgements}

This work was supported by the Medical Research Service of the Department of Veterans Affairs and USPS grant AG11465.

\section{References}

Alvarez R, Anres J, Yubero P, Vinas O, Mampel T, Iglesias R, Giralt M \& Villarroya F 1995 A novel regulatory pathway of brown fat thermogenesis: retinoic acid is a transcriptional activator of the mitochondrial uncoupling protein gene. Journal of Biological Chemistry 270 5666-5673.

Auwerx JP, Leroy E \& Schoonjans K 1992 Lipoprotein lipase: recent contributions from molecular biology. Critical Reviews in Clinical Laboratory Sciences 29 243-268.

Bianco AC, Sheng X \& Silva JE 1988 Triiodothyronine amplifies norepinephrine stimulation of uncoupling protein gene transcription by a mechanism not requiring protein synthesis. Journal of Biological Chemistry 261 18168-18175.

Bradford M 1976 A rapid and sensitive method for the quantitation of microgram quantities of protein utilizing the principle of protein-dye binding. Analytical Biochemistry 72 248-254.

Campfield LA, Smith FJ, Guisez Y, Devos R \& Burn P 1995 Recombinant mouse ob protein: evidence for a peripheral signal linking adiposity and central neural networks. Science 269 546-549.

Chomczynski P \& Sachhi N 1987 Single step method of RNA isolation by acid guanidinium thiocyanate-phenol-chloroform extraction. Analytical Biochemistry 162 156-159.

De Vos, Saladin R, Auwerx J \& Staels B 1995 Induction of ob gene expression by corticosteroids is accompanied by body weight loss and reduced food intake. Journal of Biological Chemistry $\mathbf{2 7 0}$ 15958-15961.

Hamman A, Flier JS \& Lowell BB 1996 Decreased brown fat markedly enhances susceptibility to diet-induced obesity, diabetes, and hyperlipidemia. Endocrinology 137 21-29.

Himms-Hagen J 1989 Brown adipose tissue thermogenesis and obesity. Progress in Lipid Research 28 67-115.

Himms-Hagen J 1990 Brown adipose tissue thermogenesis: interdisciplinary studies. FASEB Journal 4 2890-2898.

Kozak LP, Britton UC \& Wells JM 1988 The mitochondrial uncoupling protein gene. Journal of Biological Chemistry 263 $12272-12277$.

Labarca C \& Paigen K 1980 A simple, rapid, and sensitive DNA assay procedure. Analytical Biochemistry 102 344-352.

Li H, Matheny M \& Scarpace PJ 1997 Beta(3)-adrenergic-mediated suppression of leptin gene expression in rats. American Journal of Physiology 272 E1031-E1036.

Lowell BB \& Flier JS 1997 Brown adipose tissue, $\beta_{3}$-adrenergic receptors and obesity. Annual Review in Medicine 48 307-316. 
Mantzoros CS, Qu D, Fredrich RC, Susulic VS, Lowell BB, Maratos-Flier E \& Flier JS 1996 Activation of beta(3)-adrenergic receptor suppresses leptin expression and mediates a-leptinindependant inhibition of food intake in mice. Diabetes 45 909-914.

Meier CA 1995 Advances in the understanding of the molecular basis of obesity. European Journal of Endocrinology 133 761-763.

Moinat M, Deng C, Muzzin P, Assimacopolulos-Jeannet J, Seydoux J, Dulloo A \& Giacobino J 1995 Modulation of obese gene expression in rat brown and white adipose tissues. Federation of European Biochemical Societies Letters 373 131-134.

Moriscot A, Rabelo R \& Bianco AC 1993 Corticosterone inhibits uncoupling protein gene expression in brown adipose tissue. American Journal of Physiology 265 E81-E87.

Murakami T \& Shima K 1995 Cloning of rat obese cDNA and its expression in obese rats. Biochemical and Biophysical Research Communications 209 944-952.

Nedergaard J, Herron D, Jacobsson A, Rehnmark S \& Cannon B 1995 Norepinephrine as a morphogen? Its unique interaction with brown adipose tissue. International Journal of Developmental Biology 39 827-837.

Pelleymounter MA, Cullen MJ, Baker MB, Hecht R, Winters D, Boone T \& Collins F 1995 Effects of the obese gene product on body weight regulation in ob/ob mice. Science 269 540-543.

Puigserver P, Vazquez F, Bonet ML, Pico C \& Palou A 1996 In vitro and in vivo induction of brown adipocyte uncoupling protein (thermogenin) by retinoic acid. Biochemical Journal 317 827-833.

Rabelo R, Reyes C, Schifman A \& Silva JE 1996 A complex retinoic acid response element in the uncoupling protein gene defines a novel role for retinoids in thermogenesis. Endocrinology 137 3488-3496.

Saladin R, De Vos P, Guerre-Milo M, Leturque A, Girard J, Staels B \& Auwerx J 1995 Transient increase in obese gene expression after food intake or insulin administration. Nature 377 527-529.
Scarpace PJ \& Matheny M 1996 Thermogenesis in brown adipose tissue with age: post-receptor activation by forskolin. Pflugers Archives European Journal of Physiology 431 388-394.

Scarpace PJ, Matheny M \& Borst SE 1992 Thermogenesis and mitochondrial GDP binding with age in response to the novel agonist CGP-12177A. American Journal of Physiology 262 E185-E190.

Scarpace PJ, Matheny M, Borst SE \& Tymer N 1994 Thermoregulation with age: role of thermogenesis and uncoupling protein expression in brown adipose tissue. Proceedings of the Society for Experimental Biology and Medicine 205 154-161.

Scarpace PJ, Tse C \& Matheny M 1996 Thermoregulation with age: restoration of beta(3)-adrenergic responsiveness in brown adipose tissue by cold exposure. Proceedings of the Society for Experimental Biology and Medicine 211 373-380.

Scarpace PJ, Matheny M, Pollock BH \& Tymer N 1997 Leptin increases uncoupling protein expression and energy expenditure. American Journal of Physiology 273 E226-E230.

Silva JE 1988 Full expression of uncoupling protein gene requires the concurrence of norepinephrine and triiodothyronine. Molecular Endocrinology 2 706-713.

Trayhurn P, Duncan JS \& Rayner DV 1995a Acute cold-induced suppression of ob (obese) gene expression in white adipose tissue of mice: mediation by sympathetic system. Biochemical Journal 311 729-733.

Trayhurn P, Duncan JS \& Rayner DV 1995 beffects of fasting and refeeding on ob gene expression in white adipose tissue of lean and obese (ob/ob) mice. FEBS Letters 488-490.

Received 16 April 1997

Revised manuscript received 16 October 1997 Accepted 24 November 1997 